\title{
THE PREVENTION OF MICROBIOLOGICAL DETERIORATION OF JUTE POTATO-BAGS DURING STORAGE ${ }^{1}$ )
}

\author{
H. J. HUECK (Central Laboratory T.N.O., Delft), \\ B. G. OPHUIS ${ }^{2}$ ) and J. C. HESEN (Institute for Research on Storage \\ and Processing of Agricultural Products (IBVL), Wageningen)
}

\section{SUMMARY}

1. The prevention of microbiological deterioration in jute bags for potatoes was studied by applying several rot-proofing treatments to the bags, and subjecting them to soil burial tests and storage with potatoes during 4 months at $5^{\circ} \mathrm{C}$.

2. Apart from the efficiency of the fungicides used, their side-effects were studied by determining their influence on taste and sprouting of the potatoes. Moreover, fungicidal residues were determined after storage with a view to health risks.

3. It was found that several impregnations with coppercontaining fungicides gave a fair to good protection against microbiological deterioration in stored jute bags. Impregnations with tributyltin and D.D.M. were also acceptable.

4. The protection afforded to jute by nearly all fungicides in the soil burial test was better than that in storage, though microbial attack in the soil burial test was demonstrable as very much more severe. This phenomenon was tentatively explained as being either due to the different microfloras involved or to the occurrence of damage caused by sprouting of potatoes in the storage experiment, sprouting not being influenced by fungicides.

5. As to side-effects, only laurylpentachlorophenol (LPCP) demonstrated a decidedly unfavourable influence on the taste of the stored potatoes. The influence in all other cases on taste and sprouting was absent or negligible. In the cases studied, fungicidal residues were not demonstrable.

6. In a special experiment it could be shown that the use of rot-proofed bags not properly dried after the impregnation must be avoided, because residues of volatile solvents probably may give rise to severe superficial damage of the potatoes.

7. Evaluating the rot-proofing treatments according to overall performance, it was found that the most expensive treatment, viz. D.D.M. + Cu-fixation, was the best. The cheapest treatment, viz. Cuprammonium, was acceptable, alongside with $\mathrm{Cu}$-8-oxyquinolinolate, tributyltin and D.D.M. Not recommended were LPCP, because of its influence on taste, not compensated by favourable other features and Cu-naphthenate, which compound, though active in our experiments, showed an overall low performance compared with other treatments.

\section{INTRODUGTION}

Jute bags constitute a major item in the packing of agricultural produce. They are much used in the transport and storage of potatoes, their strength and relative cheapness being highly appreciated. One of the main drawbacks, however, is their susceptibility to microbiological deterioration, which, under certain environmental conditions, may lead to a rapid loss in strength of the jute. Though the enzymatic hydrolysis of cellulose in the jute fibre, caused by fungi and bacteria, is by no means the sole cause of deterioration in practice (Armstrong, 1941) it will be the chief factor at any rate in a damp environ-

\footnotetext{
1) Received for publication December 24, 1959.

2) Present address "Centraal Bureau" G.A., Nationale Coöperatieve Aan- en Verkoop vereniging voor de Landbouw, Rotterdam.
} 
ment. The phenomenon, which is long known as rotting has been reviewed several times (cf. Thaysen et al. (1939), Basu (1948), Burgess (1954), Wessed (1954)).

Under storage conditions, high humidities will be of frequent occurrence. BASU (1948) states that at a relative humidity of $85 \%$, which corresponds with a water content of the fibre of $12 \%$, development of fungi is already possible. Secondary factors such as temperature, type of jute, soiling etc. will be of influence too, so that a certain variation in the occurrence of rotting during storage is apparent in practice. Nevertheless, it seems to be rather common in the Netherlands.

The usual methods of rot-prevention are: drying and impregnation of the jute fabric with a fungicide. Under storage conditions, the maintenance of a sufficiently dry atmosphere would be expensive, and not always practicable. The rot-proofing of jute bags, therefore, has to be considered as the main weapon against this type of deterioration.

MacMillan, Basu and Pal (1957) have evaluated a great many compounds as to their usefulness for the rot-proofing of jute by the application of a soil burial test, and a mixed culture test. Copper-compounds proved to be outstanding for the purpose. In the rot-proofing of jute bags for the storage of potatoes, however, not only the rot-proofing qualities of the compound must be considered, but also the absence of secondary effects which may be harmful to the potatoes. If the potatoes are to be used for consumption, their taste must not be influenced and possible residues of the fungicide shall not be injurious to health. In seed-potatoes unfavourable influences on sprouting must be avoided. Apart from these secondary effects, one wonders whether laboratory tests on rot-proofing qualities of impregnated jute have sufficient predictive value. Such laboratory-tests are generally accelerated tests carried out at high temperatures $\left( \pm 30^{\circ} \mathrm{C}\right)$, and with massive infection by micro-organisms. A reevaluation under practical conditions of rot-proofing compounds that have passed the laboratory tests, therefore, seemed to be worthwhile. Such a practical experiment, on the other hand, would offer a possibility to investigate the possible secondary effects on the potatoes as were mentioned above.

The performance of such an experiment calls for abilities of a specific nature. The authors were fortunate in that it has been possible to implement a cooperation between the biological department of the Central Laboratory T.N.O. (formerly belonging to the Fibre Research Institute T.N.O.), where rot-proofing methods are studied and the Institute for Research on Storage and Processing of Agricultural Products (IBVL), where storage problems of potatoes are investigated. The experiment was run along the following lines.

Jute bags were impregnated with different rot-proofing compounds. Because of the practical nature of the experiment, the choice of fungicides was mainly restricted to those readily obtainable in practice, with the addition of a few treatments of an experimental nature which e.g. had already proved their merits with other cellulosic fibres (cotton). The jute fabric was subjected to laboratory tests for rot-proofing, for which purpose a combination of leaching and a soil burial test appeared to be most adequate. Treated and untreated bags were then filled with potatoes, and stored in ordinary potato-storages. A few additional experiments in cold stores and an ordinary shed were also carried out. 
After storage, the quality of the jute fabric was investigated by determining the tensile strength and by subjecting it once again to a soil burial test. The quality of the potatoes after storage was judged as to taste and flesh. Finally, peels of stored potatoes were analyzed chemically as to the occurrence of any residues of the fungicides used. Because of the variation encountered in actual rotting during storage, it was deemed necessary to continue this investigation through several storage periods. Our investigation started in 1953, and apart from some studies of details, which are still going on, was finished in 1957. The present report contains the information of a practical nature, gathered in these experiments, in order to furnish a basis for the possible application in practice of the fungicides used. During the investigation, we had the opportunity to also gather information of a microbiological nature, particularly about the adequacy of the tests. These details will be published elsewhere.

\section{Materials}

\subsection{JUTE BAGS}

The jute bags normally used in our experiments were obtained from N.V. Zakkencentrale, Rotterdam, Holland; they were bags used in actual practice. The tensile strength of the fabric was about $50 \mathrm{~kg}$, and its weight about $340 \mathrm{~g}$ per bag. The number of yarns was 22 per $5 \mathrm{~cm}$. In a few instances, bags of a deviating quality had to be used.

\subsection{ROT-PROOFING COMPOUNDS}

\subsubsection{Cuprammonium process}

The cuprammonium process, also known as the Willesden process, is of long standing. Essentially, it consists in impregnating the fibre with a complex copper-compound in alkaline solution. The modification we used was the following :

Bags were treated in a bath consisting of $25 \mathrm{~g} \mathrm{CuSO}_{4} .5 \mathrm{aq}$. and $22.5 \mathrm{~g}$ $\mathrm{NH}_{4} \mathrm{OH}(24 \%)$ and $950 \mathrm{ml}$ water. This results in depositing $1 \%$ of copper expressed as metal on the fabric. The cuprammonium process confers a good and cheap rot-proof to the fabric, with a good leach resistance. Its drawback is that the fabric is rendered dusty and acquires a blue-green colour.

The treating process requires close control, in order to obtain uniformity of application, and to avoid weakening of the fabric by the corrosive fluid (WESSEL, 1954).

\subsubsection{Copper naphthenate}

Copper naphthenate is still one of the standard rot-proofing treatments though it has been known over 50 years already. "It was used extensively for sandbag protection during World War II and still is the preferred treatment for this type of fabric" (Wessel, 1954). It is of an indefinite composition, containing copper salts of naphthenic acids of which a great variety exists in a small acidic fraction of petroleum. Copper-naphthenate is applied on the basis of its copper content. It may be applied from an organic solvent or ammoniacal aqueous solution. The latter application is the more economic one. Our impregnations were carried out with Nuodex Copper NH8 in a concentration 
of $12.5 \%$ of the weight of fabric $(=1 \% \mathrm{Cu})$. The product was obtained from Nuodex Products Co., Inc., U.S.A. The rot-proof obtained with copper naphthenate is generally considered to be one of the best obtainable with fungicides. The chief drawbacks of the compound are its blue-green colour and unpleasant odour which depends upon the purity of the naphthenic acids used. A slight stiffening of the impregnated fabric is reported.

\subsubsection{Copper-8-quinolinolate}

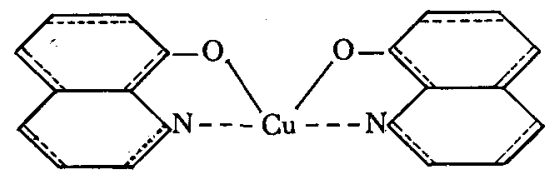

Copper-8-quinolinolate is used extensively in the U.S. for military fabrics. It possesses the high rot-proofing activity of copper compounds in general, but is only slightly coloured (yellowish-green) and has practically no odour. However, it is highly insoluble in water and other common solvents, which makes the application decidedly difficult. The conventional procedure is to use a very fine dispersion of the compound (solubilization). The preparation is rather expensive. We have the impression that the quality of the rot-proof with copper-8-quinolinolate depends very much on the brand used.

In this experiment, the impregnation was carried out in acid bath with Acryptol $\mathrm{Cu}$, a French product of the Société des Matières Colorantes, obtained from Fa. Huneus, Baarn, Netherlands, in percentages of 0.3 and $0.9 \%$ based on the weight of the fabric.

\subsubsection{Cunimene 2243}

Cunimene is a proprietary preparation which is said to contain $4 \%$ copper as $\mathrm{Cu}-\mathrm{Mg}$ dehydroabietylamino-8 hydroxychinoline-3 aethyl hexoaat. This highly active product is said to possess the good qualities of copper compounds without their drawbacks. It was applied on an experimental basis during one season only. The impregnation was carried out by immersing the bags in an aqueous solution containing $6.25 \%$ Cunimene 2243 . With a wet loading of 120 percent, the fabric contained $7.5 \%$ Cunimene 2243 , based on the weight of the fabric, which means $0.3 \% \mathrm{Cu}$.

\subsubsection{Zinc naphthenate}

Zinc naphthenate is comparable with copper naphthenate with zinc substituted for copper. It is less fungicidal than oopper naphthenate but is practically colourless. The rather high quantities needed, and the inferior resistance to leaching, warrant its use only in cases where the inclusion of copper in the fabric is to be avoided. The actual application was carried out by immersing the bags in an aqueous solution of $20 \%$ Nuodex Zn-NH8. With a wet loading of $120 \%$, the fabric contained $24 \%$ Nuodex $\mathrm{Zn} \mathrm{NH8}(=1.9 \% \mathrm{Zn})$ based on the weight of the fabric. 


\subsubsection{Phenylmercuriacetate}

Mercury compounds like phenylmercuriacetate have, at one time or another, been recommended for textile protection, probably because of their good performance in other fields of microbial control. Their solubility, however, renders them fairly leachable. In the case of jute preservation during storage, leaching may be less important than usual in textiles, so that inclusion in the program because of its high activity and relative cheapness seemed warranted. The preparation used was AAmicromul, obtained from AAgrunol, Groningen, Netherlands. The bags were immersed in an aqueous solution of $0.2 \%$ AAmicromul. This product contains $10 \%$ phenylmercuriacetate. With a wet loading of $125 \%$ the fabric contained $0.25 \%$ AAmicromul, based on the weight of fabric $(=0.025 \%$ phenylmercuriacetate).

\subsubsection{Tributyltincompounds}

The inclusion of an organic tin compound in the program appeared to be attractive, because of the high activity of this type of fungicides, developed by v. D. KerK and LuYTEN (1954). The use as a textile protectant has been considered by HUECK and LUYTEN (1958). Practical experience with tin compounds for the rot-proofing of jute is still lacking, so that the results given in this report must be considered as preliminary. The impregnation was carried out by N.V. Noury \& v. d. Lande, Deventer, Netherlands, with a researchpreparation.

In the first season (1954/55) tributyltinchloride was used. Because of its unfavourable performance this compound was replaced in the following two seasons by a tributylcompound in which the chloride was replaced by a much larger group, the nature of which was not disclosed. The proprietary name for this last fungicide is Mildoline-P. It was applicated by addition to the batch-oil during the manufacturing of the bags.

\subsection{8. $\quad$ LPCP (Laurylpentachlorophenate)}

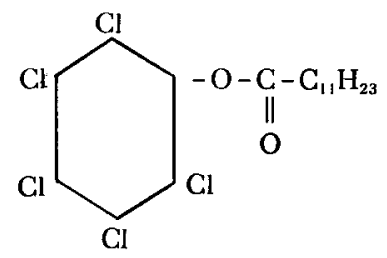

LPCP is used extensively in Great Britain and the Netherlands as a textile protectant. Published results with the compound are few (cf. HuEcK and LA BRIJN (1958)), but the type of protection appears to be the same as that shown by pentachlorophenol (PCP), though LPCP is reputedly more resistant to leaching. Its main advantage is that it is colourless, easily applied and not expensive. The permanency of PCP is doubted and the accelaration of nonbiological tendering of fabric (in sunlight) and skin-irritant properties are distinctly unfavourable. Summing up U.S. experience, WESSEL (1954) remarks. "In general it may be said that these chlorinated derivatives of phenol, though valuable as fungicides in other fields, have been found unsuitable for most general textile items". Because of its popularity in Holland, the compound was 
nevertheless included in the program. The preparation used was Mystox L.S., obtained from Catomance Ltd., Herts., England.

Bags were immersed in an aqueous solution of $3.2 \%$ Mystox L.S. With a wet loading of $125 \%$ the fabric contained $4 \%$ Mystox L.S. (= 1\% LPCP) based on the weight of fabric.

In 1955 , bags commercially impregnated with $4 \%$ of a preparation called "Rottex" were obtained by courtesy of Messrs. Haak, Rotterdam. This preparation according to this firm, contained also LPCP as an active substance. The said bags were not of the type ordinarily used in our investigation.

2.2.9. D.D.M. (2,2'-Methylenebis(4-Chlorophenol))

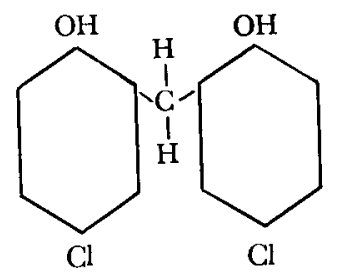

D.D.M. is one of the so-called bisphenols, which have a very good reputation as antiseptics and desinfectants. Next to copper naphthenate and copper8-oxyquinolinolate, D.D.M. is one of the standard textile protectants of the U.S. Army. It is practically colourless and odourless. It is not very resistant to leaching, which drawback, in our experience, can be remedied by an aftertreatment with a copper salt. We, therefore, used DDM in our experiments, with and without such a fixation. According to Wessel (1954), D.D.M., like PCP, is suspected of accelerating damage to cellulose by sunlight, but it possesses a lower human toxicity and does not irritate the skin. It is more expensive than PCP, and it appears that it is used in the U.S. in cases where in Europe, PCP or LPCP is applied. In our investigation, the preparation used was Preventol G.D. obtained from Bayer A.G. Bags were immersed in an aqueous solution of $1.7 \%$ Preventol G.D. With a wet loading of $120 \%$ the fabric contained 2\% Preventol G.D. based on the weight of fabric.

Copper fixation was carried out by immersing the bags in an aqueous solution $2.5 \% \mathrm{CuSO}_{4} .5 \mathrm{H}_{2} \mathrm{O}$. With a wet loading of $120 \%$, the fabric contained $0.8 \% \mathrm{Cu}$ based on the weight of fabric.

\subsection{Potatoes}

Throughout our experiments potatoes of the varieties Eigenheimer, in the case of potatoes for consumption, and Bintje, in the case of seed-potatoes, were used.

\section{Methods}

\subsection{SoIL bURIAL TEST}

Soil burial tests were carried out according to the specification Vitno Bio A 1, which, in general outline, is identical with the U.S. Federal Specification CCC $\mathrm{T} 191 \mathrm{~b}$ Method 5762. For the purpose ravelled strips of jute of a width of $5 \mathrm{~cm}$ and a length of $25 \mathrm{~cm}$ are buried in a soil mixture consisting 
of compost, sand and well-shredded manure $1: 1: 1$. The strips are incubated during 14 days at $30^{\circ} \mathrm{C}$, whilst the moisture content of the soil mixture is maintained at about $25 \%$. After the burial period, the tensile strength of the buried strips is determined, along with that of the same number of unburied strips, using a Zwick dynamometer for the purpose. The distance between the jaws was $15 \mathrm{~cm}$ and the velocity of the moving clamp $10 \mathrm{~cm} / \mathrm{min}$. Comparison of the strength after burial with the strength before burial offers a measure for the amount of deterioration due to microbial attack. For each determination of tensile strength, in general the mean of about 20 strips was used.

\subsection{LEACHING}

Leaching is a standard procedure in the evaluation of rot-proofed textiles, because it gives some insight in the adherence of the fungicide to the fibre. It is used in combination with a biological test, like the soil burial test. The performance of the fabric in such a test, before and after leaching, is a measure for the said adherence of the fungicide to the fibre. Leaching was carried out according to the specification ASTM-D 862-45T-1950, which means a leaching during 36 hours in running tap-water.

In order to obtain results in storage, comparable with those in the soil burial test, leached as well as unleached bags were used in the storage experiments. Because of a comparatively small amount of information derived from it, this practice was discontinued in the last run of storage exposures.

\subsection{Storage}

In general storage of the bags filled with $20 \mathrm{~kg}$ of potatoes was carried out in a normal, ventilated potato-storage of the "Coöperatieve Telersvereniging "de Bommelerwaard" at Kerkwijk". The bags were piled random in the storage room, mixed with potato-bags not partaking in the experiment. During storage the bags were re-positioned several times. Temperature of the storage room centered around $5^{\circ} \mathrm{C}$, relative humidity was generally very high, viz. about 95\%. Storage lasted about 4 months in the period Nov.-April. Variations on the scheme in each storage run were inevitable. In the experiment finished in 1954, a comparison was made between bags in the lower part of the pile and those in the upper layers. In the experiments finished in 1955, a comparison was made between storage in a cold store with mechanical cooling and an unventilated storage shed of the older type. Results of these comparisons will be recorded separately.

After storage, the general appearance of the potatoes was noted and compared for the treatments involved. These observations gave rise to a special experiment on the influence of wet impregnated bags on the appearance of potato-tubers. The details of this experiment will be recorded in connection with the appropriate results.

\subsection{SProuting-ABILITY}

Seed potatoes were stored, under the same conditions as described above, in separate bags. Near the end of the storage season, part of the potatoes were harvested and placed at a higher temperature (about $15^{\circ} \mathrm{C}$ ) in wooden 
cases in order to sprout. Germ weights per 100 tubers were determined and compared with those of potatoes in untreated bags.

\subsection{INFLUENCE OF THE ROT-PROOFING TREATMENT ON TASTE OF POTATOES}

The possible influence of the fungicidal treatment of the bags on the taste of the potatoes stored in them was determined organoleptically by a group of persons acquainted with this type of work. Qualifications were reached, by ranking the quality of cooked potatoes.

\subsection{ANALysis of FUNGicidal Residues}

The analysis of fungicidal residues on the potatoes after storage was carried out by Ir. F. J. v. LAMOEN of the Fibre Research Institute T.N.O., Delft.

According to his report, the following methods or reagents were applied.

Copper Reaction with diethyldithiocarbamaat according to Dekker.

Zinc Reaction with ammonia mercuric rhodanide and, separately, with diphenylamine.

Mercury Reaction with dithizon and, separately, with diphenylcarbazide, according to Feigl.

LPCP Colorimetric determination after reaction with a copper-pyridine reagent.

For the purpose, the potatoes were peeled. The reactions were carried out with the peels and the flesh separately.

\section{Results}

\subsection{EFFICIENCY of THE ROT-PROOFING treatMENT}

Our main effort in the determination of the efficiency in preventing deterioration of the various rot-proofing treatments was directed towards a comparison of the quality of the jute fabric in question, before and after storage. As pointed out before, soil burial and leaching were applied for the purpose, whilst tensile strength of the fabric was used as the final measure. The mean strength-values obtained in this way are summarized in table 1 . It will be remembered that each value is the mean of about 20 determinations.

For a better understanding of the results, a certain rearrangement of the raw data of table 1 may be helpful. It is clear, e.g., that great variations exist in the original strength of the jute bags, due to the influence of the impregnating-process, the leaching procedure and the use of different qualities of jute. We may account for this by calculating the residual strength, viz. the percentage of the original strength remaining after storage, soil burial, etc. Furthermore, we should like to have a measure for the degree of protection afforded by each treatment. For this purpose, the difference between the residual strength of treated and untreated samples may be used, but it will be clear that it makes a difference whether the untreated sample was heavily attacked or not. An expression like the following appears therefore adequate. It may be called the degree of protection, expressed as a percentage. 
Table 1 Tensile strength in $\mathrm{kg}$ of jute fabric, before and after storage with potatoes under influence of soil burial and leaching.

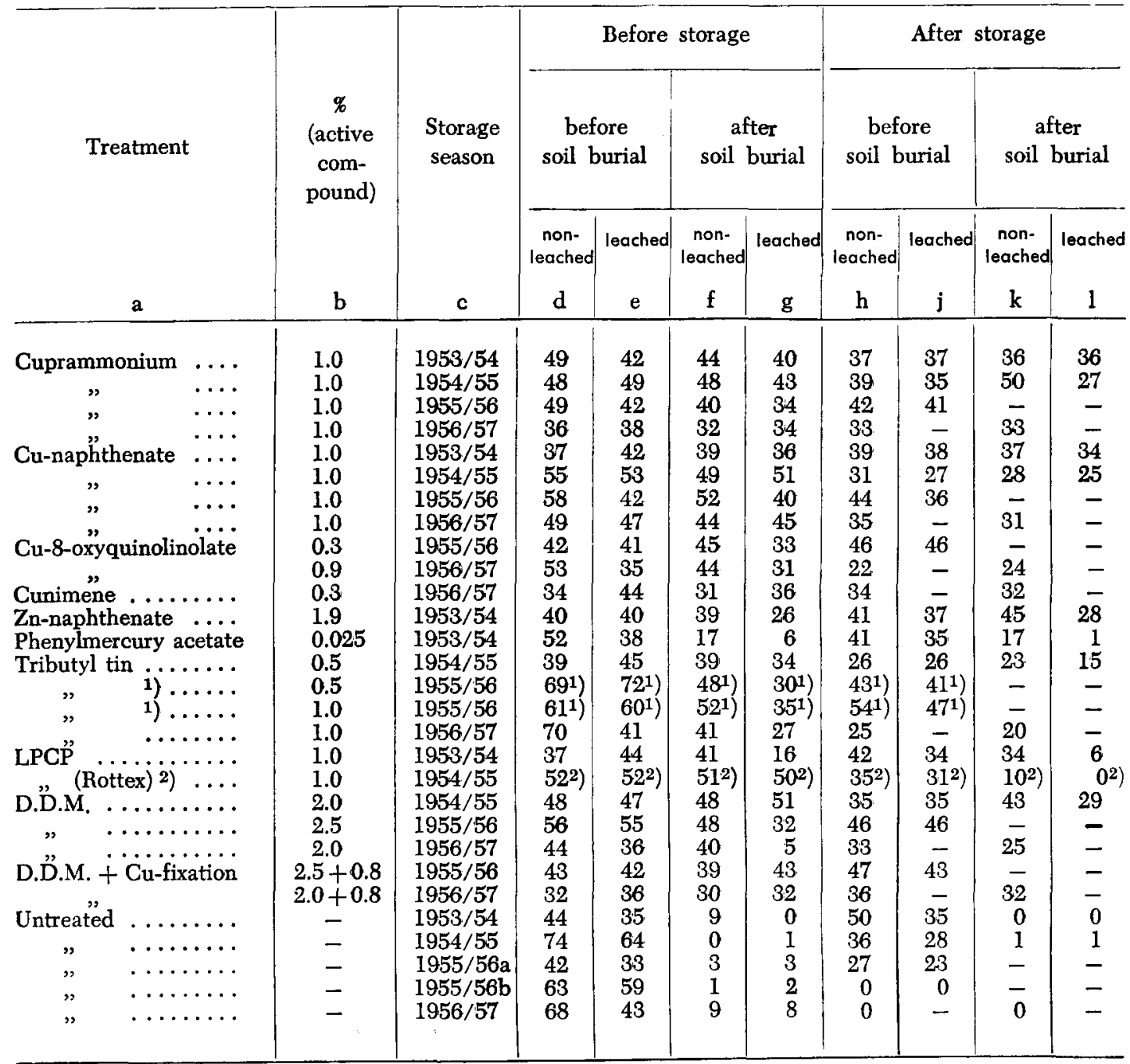

The tin compound used in 1954/55 was tributyltinchloride. In 1955/56 and 1956/57 another tributyltincompound was used as indicated on page 19.

The percentages of the copper-compounds used are expressed as $\%$ of copper.

1) Jute fabric of a deviating quality was used. The appropriate untreated sample is $1955 / 56 \mathrm{~b}$.

2) Jute fabric of an unknown quality was used.

$P=\frac{t-b}{100-b} \times 100$

$\mathrm{P}=$ degree of protection,

$\mathrm{t}=$ residual strength of the treated sample,

$\mathrm{b}=$ residual strength of the untreated sample.

In general, $\mathrm{P}$ will show positive values between 0 and 100 , but negative 
values may occur, which means that the treatment has an unfavourable influence on the fabric, surpassing the effect of the microbiological deterioration encountered. This may be due to chemical breakdown of the fibre, etc. Values above 100 are mostly due to chance variations, they will be recorded as $100^{+}$.

Finally we may calculate from table 1 a measure for the amount of fungicide left after storage by expressing the data of column $k$ as a percentage of column $h$ and those of $l$ of column $j$. This figure, which will be called the percentage retention of rot-proof, must be compared with the appropriate residual strength before storage.

It will be realized that the accuracy of the data given is not very high. Though, variation coefficients etc. have been calculated, it appears that a

Table 2 Residual strength of jute fabric after soil burial and storage, retention of rot-proof after storage and degree of protection in soil burial and storage due to various rotproofing treatments.

\begin{tabular}{|c|c|c|c|c|c|c|c|c|c|c|c|}
\hline \multirow{3}{*}{ Treatment } & \multirow{3}{*}{$\begin{array}{l}\text { Storage } \\
\text { season }\end{array}$} & \multicolumn{4}{|c|}{ Residual strength (\%) } & \multirow{2}{*}{\multicolumn{2}{|c|}{$\begin{array}{c}\text { Retention of } \\
\text { rot proof } \\
\text { after storage } \\
\%\end{array}$}} & \multicolumn{4}{|c|}{ Degree of protection (\%) } \\
\hline & & \multicolumn{2}{|c|}{$\begin{array}{l}\text { after soil } \\
\text { burial }\end{array}$} & \multicolumn{2}{|c|}{$\begin{array}{l}\text { after } \\
\text { storage }\end{array}$} & & & \multicolumn{2}{|c|}{$\begin{array}{l}\text { in soil } \\
\text { burial }\end{array}$} & \multicolumn{2}{|c|}{ in storage } \\
\hline & & \begin{tabular}{|c} 
non- \\
leached \\
$\mathrm{c}$
\end{tabular} \mid & $\begin{array}{c}\text { leached } \\
\mathrm{d}\end{array}$ & $\mid \begin{array}{c}\text { non- } \\
\text { leached } \\
\mathrm{e}\end{array}$ & $\begin{array}{c}\text { leached } \\
\mathrm{f}\end{array}$ & $\begin{array}{c}\text { non- } \\
\text { leached } \\
\mathrm{g}\end{array} \mid$ & $\begin{array}{c}\text { leached } \\
\mathrm{h}\end{array}$ & $\left|\begin{array}{c}\text { non- } \\
\text { leached } \\
\mathrm{j}\end{array}\right|$ & $\begin{array}{c}\text { leached } \\
\mathbf{k}\end{array}$ & $\mid \begin{array}{c}\text { non- } \\
\text { leached } \\
1\end{array}$ & $\begin{array}{c}\text { leached } \\
\mathbf{m}\end{array}$ \\
\hline Cuprammonium $\ldots$. & $1953 / 54$ & 90 & 95 & 76 & 88 & 97 & 97 & 88 & 95 & - & - \\
\hline$\Rightarrow \quad \ldots$ & $1954 / 55$ & 100 & 87 & 81 & 71 & 128 & 77 & 100 & 88 & 63 & 48 \\
\hline ", & $1955 / 56$ & 82 & 81 & 86 & 98 & - & - & 81 & 79 & 67 & 93 \\
\hline$C$ & $1956 / 57$ & 89 & 90 & 93 & - & 100 & - & 87 & 90 & 93 & - \\
\hline Cu-naphthenate $\ldots$. & $1953 / 54$ & 105 & 86 & 105 & 90 & 95 & 89 & $100^{+}$ & 86 & - & - \\
\hline$\Rightarrow \quad \ldots$ & $1954 / 55$ & 89 & 96 & 56 & 51 & 90 & 93 & 89 & 96 & 14 & 13 \\
\hline$\ldots$ & $1955 / 56$ & 90 & 95 & 76 & 86 & - & - & 89 & 94 & 33 & 53 \\
\hline$C_{0}, \cdots$ & $1956 / 57$ & 89 & 96 & 72 & 17 & 88 & - & 87 & 95 & 72 & - \\
\hline Cu-8-quinolinolate.. & $1955 / 56$ & 107 & 80 & 110 & 112 & - & - & $100+$ & 78 & $100+$ & $100^{+}$ \\
\hline Cunimene $\ldots \ldots$. & $\begin{array}{l}1956 / 57 \\
1956 / 57\end{array}$ & $\begin{array}{l}84 \\
90\end{array}$ & $\begin{array}{l}89 \\
81\end{array}$ & $\begin{array}{r}41 \\
100\end{array}$ & $=$ & $\begin{array}{r}109 \\
96\end{array}$ & $\bar{z}$ & $\begin{array}{l}82 \\
89\end{array}$ & $\begin{array}{l}89 \\
81\end{array}$ & $\begin{array}{r}41 \\
100\end{array}$ & - \\
\hline Zn-naphthenate $\ldots$. & $1953 / 54$ & 97 & 65 & 103 & 93 & 110 & 75 & 96 & $\begin{array}{l}01 \\
65\end{array}$ & 100 & - \\
\hline Phenylmercury acetate & $1953 / 54$ & 33 & 16 & 79 & 92 & 41 & 3 & 16 & 16 & - & - \\
\hline Tributyl tin 1) $\ldots \ldots$ & $1954 / 55$ & 100 & 76 & 67 & 58 & 88 & 58 & 100 & 76 & 35 & 25 \\
\hline$"$ & $1955 / 56 \mathrm{a}$ & 70 & 42 & 62 & 57 & - & - & 68 & 36 & -6 & -43 \\
\hline$"$ & $1955 / 56 \mathrm{~b}$ & 85 & 58 & 89 & 78 & - & - & 85 & 57 & 89 & 78 \\
\hline " & $1956 / 57$ & 59 & 66 & 36 & - & 80 & - & 53 & 66 & 36 & - \\
\hline LPCP $\ldots \ldots$ & $1953 / 54$ & 111 & 36 & 114 & 77 & 81 & 16 & $100+$ & 36 & - & - \\
\hline (Rottex) & $1954 / 55$ & 98 & 93 & 67 & 57 & 29 & 0 & 98 & 93 & 35 & 23 \\
\hline D.D.M, $\ldots \ldots$ & $1954 / 55$ & 100 & 109 & 73 & 74 & 123 & 83 & 100 & $100+$ & 47 & 54 \\
\hline$"$ & $5 / 56$ & 86 & 58 & 82 & 84 & - & - & 85 & 54 & 50 & 47 \\
\hline & $1956 / 57$ & 92 & 14 & 76 & - & 74 & - & 92 & 12 & 76 & - \\
\hline D.D.M. + Cu-fixation & $1955 / 56$ & 91 & 102 & 109 & 102 & - & - & 90 & $100+$ & $100+$ & $100+$ \\
\hline & & 93 & 88 & 112 & - & 89 & - & 92 & 88 & $100+$ & - \\
\hline Untreated & $1953 / 54$ & 20 & $\mathbf{0}$ & 114 & 100 & - & - & 0 & 0 & - & - \\
\hline ", & $1954 / 55$ & 0 & 1 & 49 & 44 & - & - & 0 & 0 & 0 & 0 \\
\hline 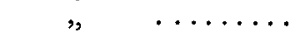 & $1955 / 56 \mathrm{a}$ & 7 & 9 & 64 & 70 & - & - & 0 & 0 & 0 & 0 \\
\hline 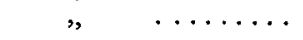 & $1955 / 56 \mathrm{~b}$ & 1 & 2 & 0 & 0 & - & - & 0 & 0 & 0 & 0 \\
\hline 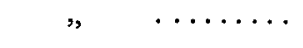 & $1956 / 57$ & 13 & 1 & 0 & - & - & - & 0 & 0 & 0 & 0 \\
\hline
\end{tabular}

1) cf remark on tin compounds in table 1. 
proper statistical treatment of the results is no simple matter, apart from the fact that the whole experiment is probably not homogeneous enough for it.

To give yet an idea of the accuracy reached, we may state that in our experience variations of $10 \%$ to either side of the mean in the calculated residual strengths are not uncommon. Conclusions, therefore, preferably should be drawn only on the basis of consistent behaviour of the fungicides in a number of experiments.

The data discussed above are shown in table 2 .

It will be noted that the degree of protection after storage in 1953/54 can not be calculated, because no microbiological deterioration occurred. A further simplification of results is given in graph 1 , where the mean degrees of protection in 1955/56 and 1956/57 are given, which seasons lend themselves best for easy comparison. Moreover, conditions of storage were, in our opinion, nearest to actual practice.

Apart from the main experiment, we have to record the results of the experiments with different types of storage. In table 3, residual strengths are given of bags stored in the upper layer, or the lower layer of a pile of bags. The experiment was carried out in 1953/1954.

For the sake of comparison, soil burial data are added to this table.

Table 3 Residual strength of jute $(\%)$ after storage with potatoes in different positions compared with soil burial. Original strength $=100$.

\begin{tabular}{|c|c|c|c|c|c|c|}
\hline \multirow{3}{*}{ Treatment } & \multicolumn{3}{|c|}{ Non-leached samples } & \multicolumn{3}{|c|}{ Leached samples } \\
\hline & \multirow{2}{*}{$\begin{array}{c}\text { soil } \\
\text { burial }\end{array}$} & \multicolumn{2}{|c|}{ storage } & \multirow[b]{2}{*}{$\begin{array}{c}\text { soil } \\
\text { burial }\end{array}$} & \multicolumn{2}{|c|}{ storage } \\
\hline & & $\begin{array}{l}\text { upper } \\
\text { layer }\end{array}$ & $\begin{array}{l}\text { lower } \\
\text { layer }\end{array}$ & & $\begin{array}{l}\text { upper } \\
\text { layer }\end{array}$ & $\begin{array}{l}\text { lower } \\
\text { layer }\end{array}$ \\
\hline $\begin{array}{l}\text { Cuprammonium } \ldots \ldots \\
\text { Cu-naphthenate } \ldots \ldots \ldots \\
\text { Zn-naphthenate } \ldots \ldots \ldots \\
\text { Phenylmercury acetate } \ldots \\
\text { LPCP } \ldots \ldots \\
\text { Mean of treated samples } \\
\text { Untreated } \ldots \ldots \ldots \ldots\end{array}$ & $\begin{array}{r}90 \\
105 \\
97 \\
33 \\
111 \\
87 \\
20\end{array}$ & $\begin{array}{r}104 \\
138 \\
115 \\
85 \\
111 \\
111 \\
114\end{array}$ & $\begin{array}{r}76 \\
105 \\
103 \\
79 \\
114 \\
95 \\
114\end{array}$ & $\begin{array}{r}95 \\
86 \\
65 \\
16 \\
36 \\
60 \\
0\end{array}$ & $\begin{array}{r}124 \\
95 \\
93 \\
113 \\
75 \\
100 \\
97\end{array}$ & $\begin{array}{r}88 \\
90 \\
93 \\
92 \\
77 \\
88 \\
100\end{array}$ \\
\hline
\end{tabular}

In the storage season $1954 / 1955$, a comparison was made between coldstore at constant $4^{\circ} \mathrm{C}$ in mechanically cooled cell and storage in a nonventilated shed. Though no exact temperature record was kept, the temperature in the shed was generally somewhat higher than that in cold-store. After the storage season, the potatoes in the shed showed more sprouting than in cold-store. The results are shown in table 4, expressed as percentages residual strength. Soil burial data are again added for comparison. 
Table 4 Residual strength of jute $(\%)$ after storage with potatoes in different types of store-house, compared with soil burial. Original strength $=100$.

\begin{tabular}{|c|c|c|c|c|c|c|}
\hline \multirow{2}{*}{ Treatment } & \multicolumn{3}{|c|}{ Non-leached samples } & \multicolumn{3}{|c|}{ Leached samples } \\
\hline & $\begin{array}{c}\text { soil } \\
\text { burial }\end{array}$ & $\begin{array}{l}\text { cold_. } \\
\text { store }\end{array}$ & shed & $\begin{array}{c}\text { soil } \\
\text { burial }\end{array}$ & $\begin{array}{l}\text { cold. } \\
\text { store }\end{array}$ & shed \\
\hline $\begin{array}{l}\text { Cuprammonium } \ldots \ldots \\
\text { Cu-naphthenate } \ldots \ldots \ldots \\
\text { Tributyltin } \ldots \ldots \ldots \\
\text { LPCP (Rottex) } \ldots \ldots \\
\text { D.D.M. } \ldots \ldots \\
\text { Mean of treated samples } \\
\text { Untreated } \ldots \ldots \ldots \ldots\end{array}$ & $\begin{array}{r}100 \\
89 \\
100 \\
98 \\
100 \\
97 \\
0\end{array}$ & $\begin{array}{r}121 \\
91 \\
82 \\
87 \\
96 \\
95 \\
59\end{array}$ & $\begin{array}{l}81 \\
56 \\
67 \\
67 \\
73 \\
69 \\
49\end{array}$ & $\begin{array}{r}87 \\
96 \\
76 \\
93 \\
109 \\
92 \\
1\end{array}$ & $\begin{array}{l}82 \\
92 \\
58 \\
67 \\
98 \\
79 \\
50\end{array}$ & $\begin{array}{l}71 \\
77 \\
58 \\
57 \\
74 \\
67 \\
44\end{array}$ \\
\hline
\end{tabular}

\subsection{The INFLUENCE OF ROT-PROOFIng TREATMENTS ON THE QUALITY OF STORED POTATOES}

\subsubsection{The taste of potatoes stored in rot-proofed bags}

The results of the organoleptic investigation of cooled potatoes are shown in table 5. The results are recorded as deviations from the normal taste.

Table 5 Taste deviations of potatoes, variety Eigenheimer, after storage during 4 months in rot-proofed bags at $5^{\circ} \mathrm{C}$.

\begin{tabular}{|c|c|c|c|c|c|}
\hline \multirow{2}{*}{ Treatment } & \multicolumn{5}{|c|}{ Storage season } \\
\hline & $1953 / 54$ & $1954 / 55$ & $1955 / 56$ & $1956 / 57$ & $1958 / 59$ \\
\hline 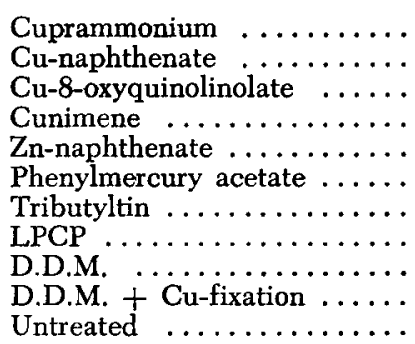 & $\begin{array}{l}\begin{array}{l}\text { none } \\
\text { slight }\end{array} \\
\text { slight } \\
\text { none } \\
\text { distinct }\end{array}$ & $\begin{array}{c}\text { distinct }{ }^{1} \text { ) } \\
\text { none } \\
\text { none }\end{array}$ & $\begin{array}{l}\text { none }{ }^{2} \text { ) } \\
\text { none } \\
\text { none } \\
\text { none }\end{array}$ & $\begin{array}{l}\text { none } \\
\text { none } \\
\text { none } \\
\text { none } \\
\text { none }{ }^{2)} \\
\text { nome } \\
\text { none } \\
\text { none }\end{array}$ & $\begin{array}{l}\text { none } \\
\text { none }\end{array}$ \\
\hline
\end{tabular}

1) tributyltinchloride.

2) a tributyltincompound other than the chloride was used as indicated on page 19.

\subsubsection{Sprouting-ability of seed-potatoes stored in rot-proofed bags}

The results of the determination of sprouting-ability after storage are recorded in table 6 . The data given are means of two separate determinations of germ-weight. 
Table 6 Germ-weights (grammes/100 potatoes) of seed-potatoes variety Bintje after storage in rot-proofed bags during 4 months at $5^{\circ} \mathrm{C}$.

\begin{tabular}{|c|c|c|c|c|c|c|c|c|c|c|}
\hline \multirow{3}{*}{ Treatment } & \multicolumn{10}{|c|}{ Storage season } \\
\hline & \multicolumn{2}{|c|}{$1953 / 54$} & \multicolumn{2}{|c|}{$1954 / 55$} & \multicolumn{2}{|c|}{$1955 / 56$} & \multicolumn{2}{|c|}{$1956 / 57$} & \multicolumn{2}{|c|}{$1958 / 59$} \\
\hline & weight & RW & weight & RW & weight & RW & weight & RW & weight & RW \\
\hline 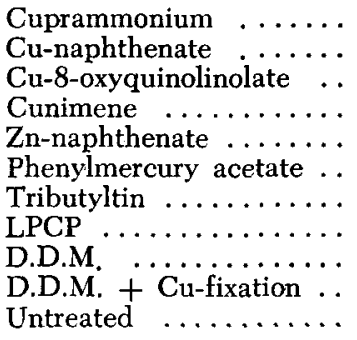 & $\begin{array}{l}288 \\
236 \\
\\
258\end{array}$ & $\begin{array}{l}124 \\
102 \\
111\end{array}$ & $\begin{array}{l}\left.323^{1}\right) \\
377\end{array}$ & $\begin{array}{l}105 \\
102\end{array}$ & $\begin{array}{l}\left.383^{2}\right) \\
387 \\
415 \\
424\end{array}$ & $\begin{array}{r}91 \\
98 \\
100\end{array}$ & $\begin{array}{l}\left.494^{2}\right) \\
526 \\
494 \\
501\end{array}$ & $\begin{array}{r}87 \\
100 \\
102 \\
94\end{array}$ & $\begin{array}{l}291 \\
333\end{array}$ & $\begin{array}{r}93 \\
106\end{array}$ \\
\hline
\end{tabular}

$\mathrm{RW}=$ relative weight. Untreated $=100$.

1) tributyltinchloride.

2) a tributyltincompound other than the chloride was used as indicated on page 19.

\subsubsection{Fungicidal residues in potatoes stored in rot-proofed bags}

From the potatoes of the 1953/54 storage season, fungicidal residues were determined. The residues of LPCP and Cu could be determined quantitatively, whereas $\mathrm{Hg}$ and $\mathrm{Zn}$ were determined with sensitive qualitative reactions. Determinations were carried out separately with the peel and the flesh of potatoes. The potatoes were derived both from the upper and the lower layer of the storage pile. Results are given in table 7.

Table 7 Fungicidal residues of potatoes after storage during 4 months in rot-proofed bags at $5^{\circ} \mathrm{C}$.

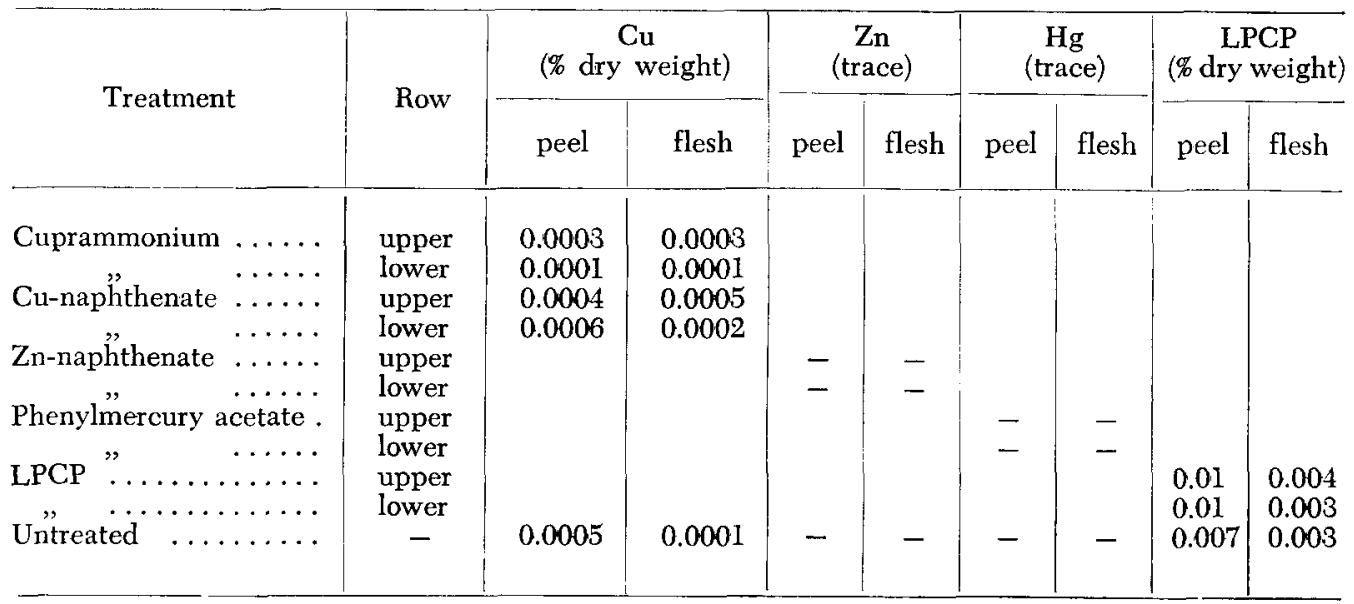

$-=$ absence of traces. 


\subsubsection{External damage of potatoes stored in rot-proofed bags}

In our experiments, the bags used were always dried after impregnation with a rot-proofing treatment. After storage, no gross external damage could be observed, even if the impregnated bags were wetted afterwards (e.g. by rain). In practice, however, damage is sometimes observed, apparently associated with the use of rot-proofed bags. It was observed in a few of such cases that damage occurred to potatoes in bags that had not been properly dried after the impregnation. The damage consists of sunken spots of necrotic tissue. The sinkings are 2-3 $\mathrm{mm}$ deep. The necrotic discoloration in the flesh seldom exceeds a few mm. (photo 1 and 2 ).

In a special experiment, it was undertaken to reproduce these phenomena. For this experiment carried out in the season $1958 / 59$, potatoes of the variety Bintje were used. Part of the potatoes were used as such, and part were slightly skinned before the exposition. For storage, bags were used impregnated with Cu-naphthenate, which were still humid and untreated ones. To prevent drying, half of the bags were each enclosed in a second plastic (polythene) bag. Each bag contained $25 \mathrm{~kg}$ potatoes, and was stored during 14 days at $15^{\circ} \mathrm{C}$. After storage the potatoes were evaluated as to the occurrence of chemical damage and rot. Results in table 8.

Table 8 Damage of potatoes in humid rot-proofed bags, stored during 14 days at $15^{\circ} \mathrm{C}$.

\begin{tabular}{|c|c|c|c|c|c|}
\hline \multicolumn{3}{|c|}{ Treatment } & \multicolumn{3}{|c|}{ Evaluation of appearance (\%) } \\
\hline & Bags & Potatoes & Undamaged & $\begin{array}{l}\text { Damaged } \\
\text { chemically }\end{array}$ & Rot \\
\hline $\begin{array}{cc}\text { Cu-naphthenate } \\
\text { " } & \\
\text { Untreated } & \ldots . \\
", & \ldots . \\
" & \ldots . \\
" & \ldots\end{array}$ & $\begin{array}{l}\text { enclosed in plastic } \\
\text { not enclosed } \\
\text { enclosed in plastic } \\
\text { not enclosed } \\
\text { ", }\end{array}$ & $\begin{array}{l}\text { whole } \\
\text { skinned } \\
\text { whole } \\
\text { skinned } \\
\text { whole } \\
\text { skinned } \\
\text { whole } \\
\text { skinned }\end{array}$ & $\begin{array}{r}31 \\
34 \\
71 \\
45 \\
100 \\
100 \\
100 \\
100\end{array}$ & $\begin{array}{r}66 \\
58 \\
27 \\
50 \\
0 \\
0 \\
0 \\
0\end{array}$ & $\begin{array}{l}3 \\
8 \\
2 \\
5 \\
0 \\
0 \\
0 \\
0\end{array}$ \\
\hline
\end{tabular}

The chemical damage found was identical with that shown in photo 2 . It was observed that damaged spots occurred especially in places where there was contact between the potato and the bag.

\section{Discussion}

\subsection{THE EFFICIENCY OF THE ROT-PROOFING TREATMENT}

In considering tables 1 and 2 , together with graph 1 , it will be noted that a fair degree of protection against deterioration may be obtained with several rot-proofing treatments of jute bags. A remarkable difference in protection between jute in the soil burial test and the storage experiment, however, exists, especially if the experiments of the seasons 1954/55 and 1955/56 are borne in mind. The effect is also clear from graph 1 . In the soil burial test, untreated jute lost all its strength in a fortnight. In the storage experiment, only about 


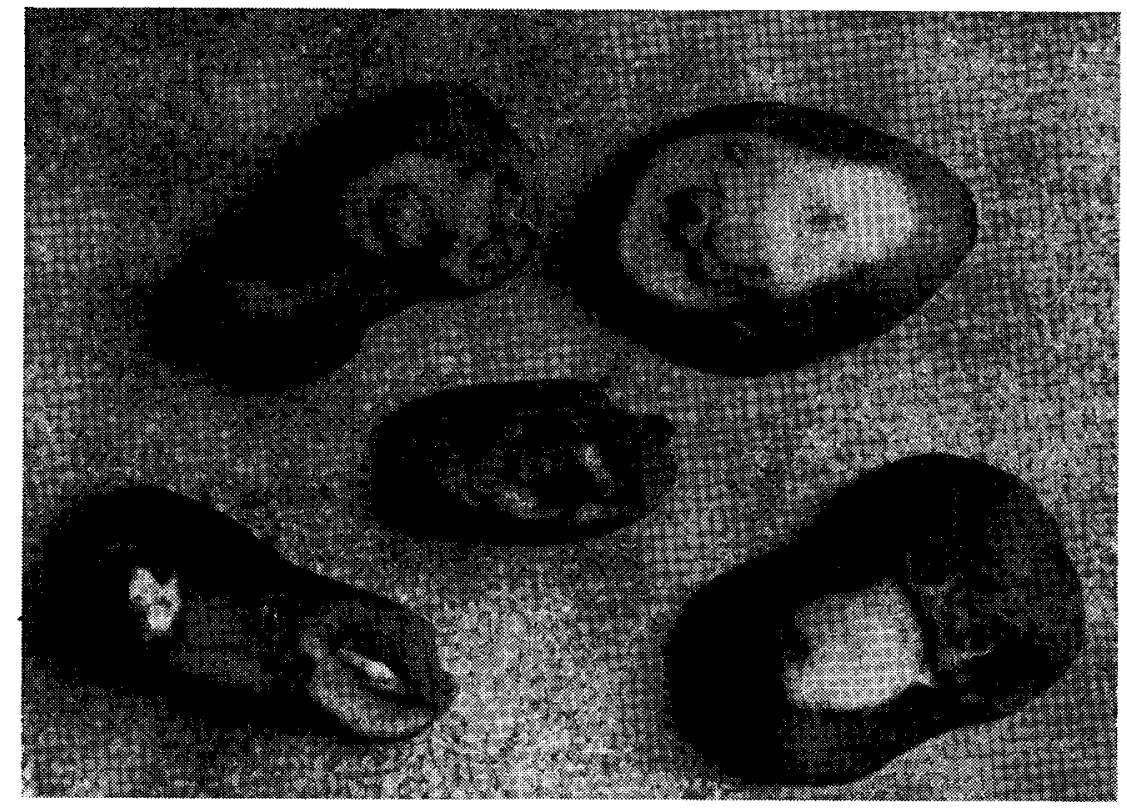

Fig. 1 Damage of potatoes caused by the USE OF Wet rot-proofed bags. The Damaged tubers have BeEn cut.

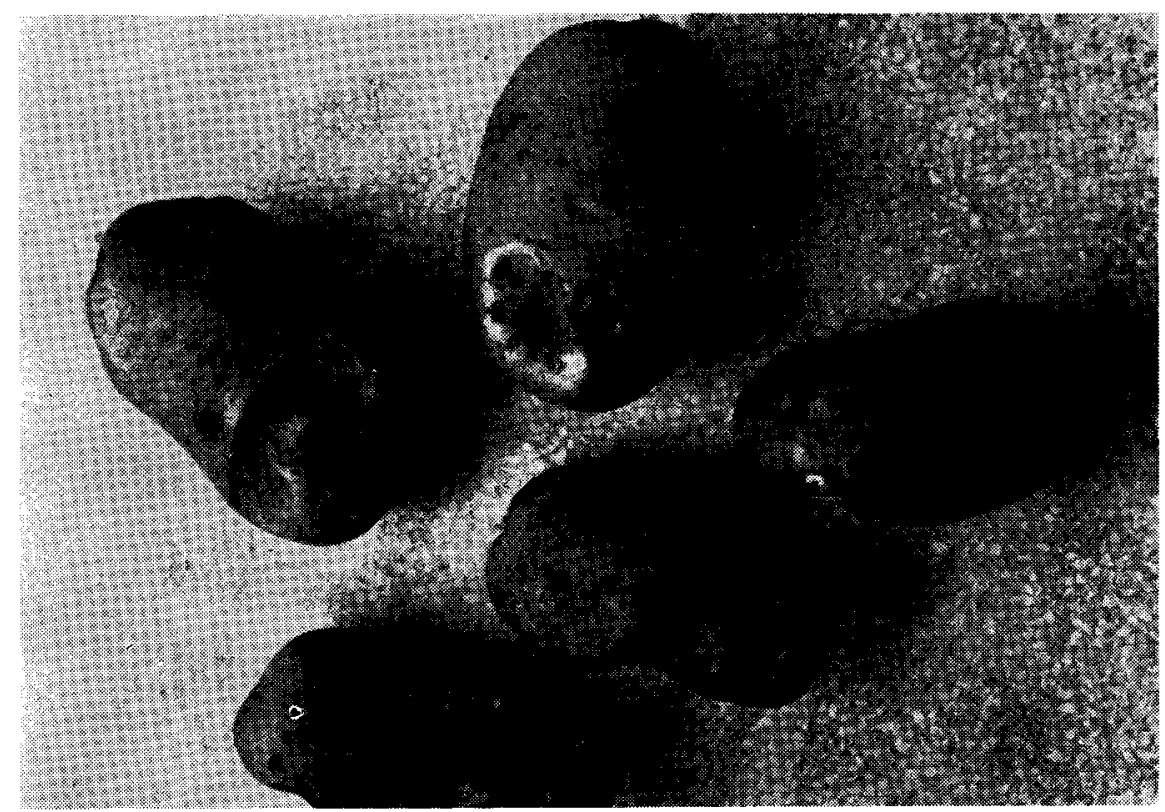

Fig. 2 Damage of potatoes CaUSEd by the USE OF Wet rot-phoofed bags. 
half the strength of the jute was lost in a period of 4 months. The microbial attack therefore, appears to be much more severe in the soil burial test. One would expect that jute, fully protected in this test, would stand the milder attack of microbes in the storage experiment also. This, however, is not the case. Though a fair degree of protection is reached here also, nevertheless the degree of protection is nearly always smaller than in the soil burial test. The predictive value of the soil burial test for storage, therefore, seems to be limited. One wonders what factors are causative in this discrepancy. One may envisage three possible ways of explanation.

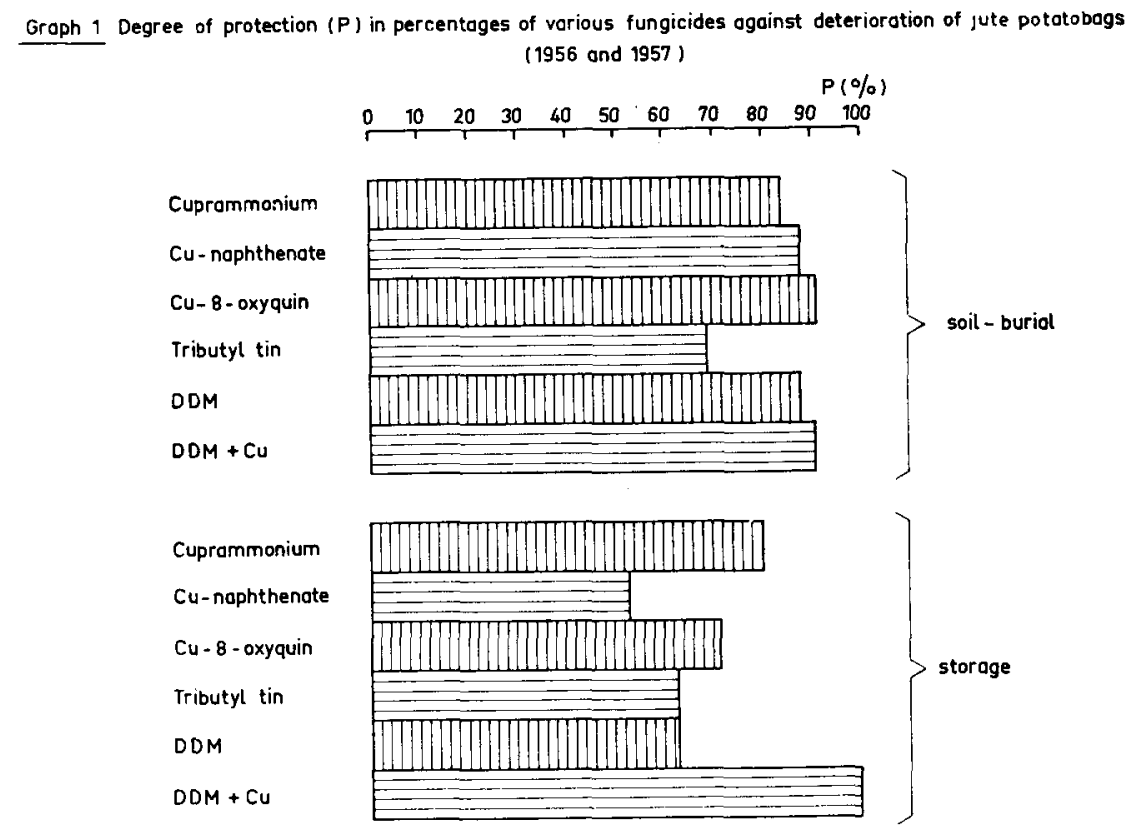

1 the storage experiment is carried out at much lower temperatures $\left(5^{\circ} \mathrm{C}\right)$ than the soil burial test $\left(30^{\circ} \mathrm{C}\right)$, which may influence the mode of action of the fungicides.

2 the microbial flora in the storage test is different in both experiments Apart from this, a certain adaptation of micro-organisms to fungicides in the long term storage experiment seems to be possible.

3 in the storage experiment additional damaging factors occur, not influenced by fungicides.

In order to distinguish between these possible explanations additional experiments are performed, the outcome of which will be published elsewhere. Already some relevant facts may be recorded.

The first explanation is not supported by the experiment shown in table 4 . Here the discrepancy between soil burial test and storage is more severe in the shed than in cold-store, though the shed certainly had a higher temperature. If the supposition were true, the effect had to be larger in cold-store.

The second explanation is supported by the fact that, indeed, we found a 
marked difference in mycoflora between the jute deteriorated in the soil, and the same in storage experiments. Apart from this, the presence of bacteria (Pseudomonas putida) in storage could be sometimes observed. The performance of the isolated strains is still being analysed, but already it was found that cellulolytic capacities of all strains are high. We must await more precise data on sensitivity towards fungicides.

The third explanation is also attractive, because it was found that, in general, after the long storage periods used in our experiments, the potatoes had sprouted. It is understandable that in the warmer shed (table 4) damage due to this factor will be more severe. We are investigating whether this type of damage is of an enzymatical, or of a mechanical nature. It will be noted that the complete protection in storage with the rot-proofing treatment D.D.M. $+\mathrm{Cu}$ does not support the third thesis.

Apart from these facts, the rot-proofing treatments nevertheless afford a degree of protection that is still considerable.

Especially the copper fungicides show a good performance. If we consider D.D.M. and D.D.M. + Cu, an appreciable increase in protection is apparent. Furthermore, the old standby cuprammonium still ranked among the best. Cu-8-oxyquinolinalate and Cunimene are decidedly promising, but further experience seems to be necessary. The non-copper fungicide LPCP, in general, was not as good as the copper containing rot-proofing treatments. This is in accordance with the findings of $\mathrm{M}_{\mathrm{AC}}$ MrLLAN et al (1957), who evaluated several rot-proofing treatments in connection with jute. D.D.M. gives a fair degree of protection, but as mentioned already, this is increased by the addition of copper.

As to storage conditions it may be remarked, that the position of the bag in the pile apparently has little significance for the problem under investigation (table 3). The type of storage on the other hand certainly may influence the conservation of the bags appreciably, as indicated in table 4 .

\subsection{SIDE-EFFECTS OF ROT-PROOFING TREATMENTS}

In table 5 , taste deviations due to the fungicidal treatment of jute are recorded. It will be seen that impregnation of the bags only in a few cases impairs the quality of the potatoes. The taste deviations with the naphthenates are so slight that in practice they will be negligible. With a view to the varying composition of these preparations, and their distinct odour, the occurrence of occasional slight taste deviations is not surprising. Properly purified preparations might show a better performance. Not negligible are the deviations with LPCP and tributyltinchloride. After replacing the chloride in the tributyltin-compound with another moiety of greater molecular weight no taste deviations could be found anymore. Impairment of taste by LPCP we think to be prohibitive for its practical application, though further experiments with modified formulations of this compound perhaps might give another impression.

Germ-weights shown in table 6 also do not give rise to unfavourable conclusions. Tributyltinchloride may be suspected of doing some damage, but the other tributyltincompound does not show this effect.

The fungicidal residues given in table 7 are not alarming. It may be concluded that no demonstrable amounts of the fungicides are taken up by the 
potatoes. From the table 8 a warning may be derived against hasty preparation and use of impregnated jute bags. It is clear that severe damage may occur in impregnated bags that are still humid. Those bags enclosed in polythene, simulating bags in the middle of piles of bags, show most damage. Not enclosed bags are much less harmful to the potatoes. Our experience that bags having been thoroughly dried after rot-proofing do not give rise to this type of damage, can be explained by pointing to the usual solvents of Cu-naphthenate. In our case, this is an aqueous solution of ammonia. Thorough drying after impregnation will make that the volatile ammonia disappears. It appears to be plausible that the damage observed must be attributed to incomplete elimination of volatile solvents of the fungicides used.

\subsection{Evaluation OF INDIVIDUAL ROT-PROOFING TREATMENTS}

After the discussion of general trends in connection with the rot-proofing of jute bags, it would seem useful to sum up the evidence gathered on the rot-proofing treatments investigated, and to evaluate them from a practical point of view. This is done in table 9.

Table 9 Practical evaluation of rot-proofing treatments for jute bags.

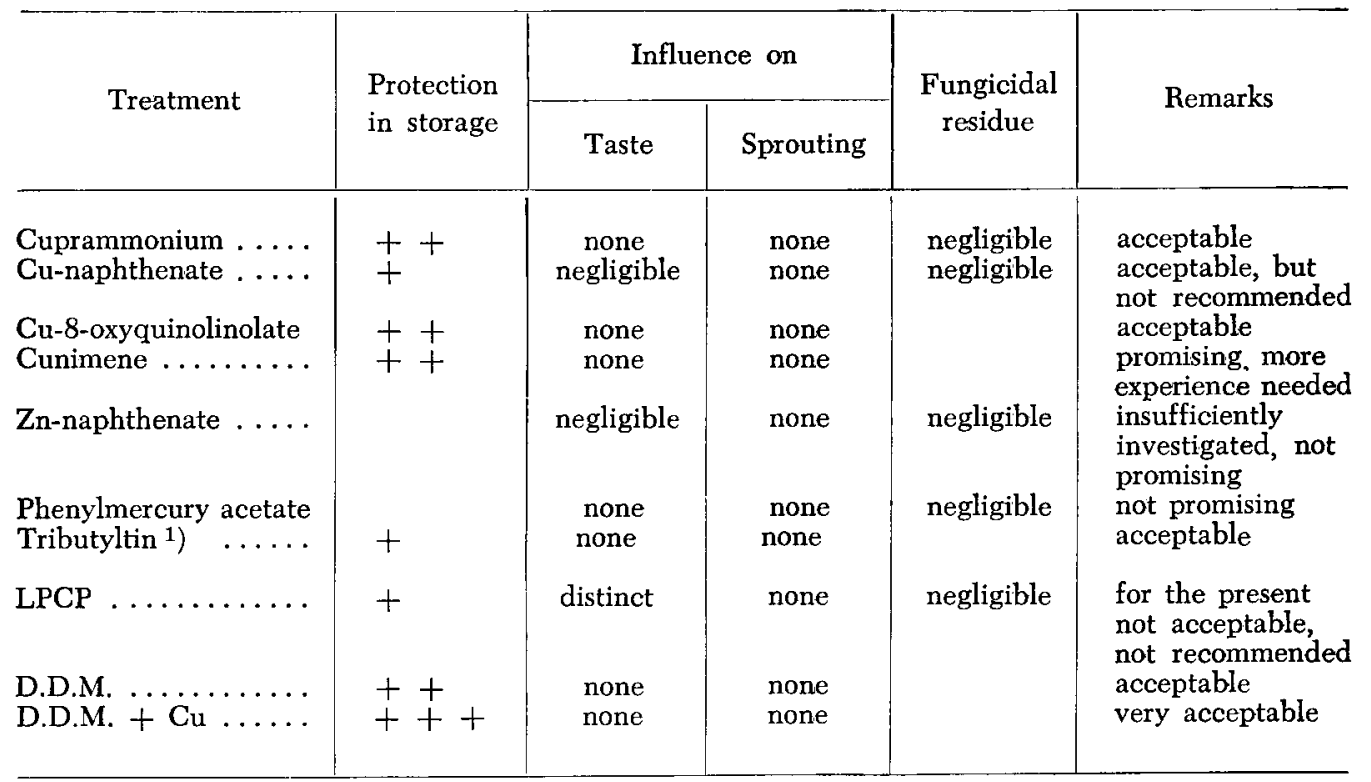

1) The evaluation pertains to mildoline-P and not to tributyltinchloride. This latter compound is unacceptable.

Legend: + some protection.

$$
\begin{aligned}
& + \\
& ++ \\
& +++ \text { good protection. }
\end{aligned}
$$

The treatments not recommended are LPCP and Cu-naphthenate. It may be added that, apart from the objectionable influence on taste, LPCP is very leachable, disappears after storage (table 2), must be suspected of doing damage to the jute fiber itself (table 5) and gives only a low degree of protection in storage. Copper naphtenate gives only a low degree of protection, and the influence on taste, though negligible, is suggestive. Technical $\mathrm{Cu}$ - 
naphtenate is a crude preparation of varying composition with a distinct nasty odour. The risk of taste influence seems not to be compensated adequately by other favourable factors.

The economics of the rot-proofing treatments have not been investigated in detail. In general, it may be remarked that the best treatment found, viz. D.D.M. + Cu, will be rather expensive, because of the additional copper-bath. Cuprammonium appears to be the cheapest impregnation. Because of the acceptable results, it may be that, in practice, this process will be widely used. A warning must be issued against applying this process lightheartedly. The process repuires expert handling, if severe damage is to be prevented. Drawbacks are, moreover, the stiffening of the fabric and the pronounced bluegreen colour. If a colourless impregnation is desired, not imparting unfavourable properties to the jute, one may choose a treatment with D.D.M. or the tributyltincompound mentioned on page 19.

\section{ACKNOWLEDGEMENT}

The authors are glad to acknowledge the assistance of Mr. J. LA BRIJN and his collaborators, and of the late Mr. E. KRoesBergen for carrying out the actual experiments. Furthermore, thanks are due to the "Coöperatieve Telersvereniging "De Bommelerwaard", at Kerkwijk", Netherlands, for storage facilities, to the Central Laboratory of N.V. Noury \& v. d. Lande for providing a research-preparation with tributyltin and to Mr. C. A. B. BuIsE of N.V. Zakkencentrale for providing jute bags. Dr. G. J. Schurninga, Deputy-Director of the Central Laboratory T.N.O., Delft, and Dr. W. H. DE Jong, Director of the Institute for Research on Storage and Processing of Agricultural Products (I.B.V.L.), Wageningen, are likewise gratefully mentioned, both for their steady interest and their permission to make the present publication.

\section{REFERENCES}

Armstrong, E. F.: The rotproofing of sandbags. Chemistry and Industry (London), 60 (1) (1941) 668-674.

BAsu, S. N. : Fungal decomposition of jute fiber and cellulose. I. A preliminary survey of commonly occurring species. J. Textile Inst. 39 (1948) T233-T237.

Burgess, R. : Micro-organisms and textiles. J. Appl. Bacteriol. 17 (2) (1954) 230-245.

Hueck, H. J. and J. G. A. Luxten: Organo-tin Compounds as Textile Preservatives. J. Soc. Dyers and Colourists 74 (1958) 476-480.

- - and J. LA BrijN : Het rotwerend maken van katoen met pentachloorphenol en laurylpentachloorphenol. De Tex 17 (8) (1958) 1057-1063.

KerK, G. J. M. vAN DER and J. G. A. LuYTEN : Investigations on organo-tin compounds. J. Appl. Chem. 4 (1954) 314.

MacMillan, W. G., S. N. BASU and P. N. PAL : Protection of jute materials against microbiological and actinic deterioration. Part I. Evaluation of some proofing agents against microbiological attack. J. Sci. Ind. Res. 16C (1957) 13-24.

Thaysen, A. C., H. J. Bunker, K. R. Butlin and L. H. Williams: The effect of climatic exposure on textile fibres and fabrics. Ann. Appl. Biol. 26 (1939) 750-781.

Wessel, C. J. : Textiles and Cordage in G. H. Greathouse and C. J. Wessel "Deterioration of Materials". Reinhold Publ. Comp., New York (1954). 